\title{
Model Direct Instruction on Service and Service Understanding in Badminton Game
}

\author{
Boby Agustan \\ Physical Education, STKIP Muhammadiyah Kuningan, Jl. Syeh Maulana Akbar, \\ Purwawinangun, Distric Kuningan, West Java, 45511, Indonesia \\ Email: bobyagustan@upmk.ac.id
}

\begin{abstract}
This study aimed to determine the effect of the direct instruction model on serviceability in badminton games. This research is a mixed method. The population in this study were VIII grade students at SMP Negeri 3 Sindangwangi Majalengka totaling 93 students. The sampling technique used was random sampling so that the study sample was obtained, namely students of class VIII.B, which amounted to 28 students. The research instruments used in this study were service tests and interviews about understanding service. The data analysis technique in this study is the normality test, and the hypothesis test is used to determine the effect of the direct instruction model on serviceability in badminton games. Based on statistical calculations for service tests obtained by $Z$ Hit (4.59)> $Z$ daf (2.35), the $H i$ received means the influence of the direct instruction model on serviceability in badminton games at a level of confidence ( $\alpha$ ) of 0.05. As for understanding service excellence, as you know, service excellence is the first attack to get points. This study concludes that there is an influence of the direct instruction model on service in badminton games. The finding is that the direct instruction model still has that is all teacher-centered instruction.
\end{abstract}

Keyword: direct instruction, service, service understanding, badminton

(C) 2021 Boby Agustan

Under the license CC BY-SA 4.0

\section{INTRODUCTION}

Physical Education Learning (Penjas/PE) is learning through traditional activities (Abduljabar, 2011). Learning will run well if each student can understand the task of moving. The study of motion contains a series of commands to do something that all students must do without exception. The characteristics of students are a challenge for teachers to be able to present good learning.

There are various ways to present a lesson. One of them is the direct instruction learning model. Direct instruction is characteristic that students are given a learning model with movement skills or concepts by organizing learning activities into separate time segments (Jumhana \& Agustan, 2016). The purpose of this model 
is to determine the most effective use of learning time efficient and to seek to increase student involvement in practical tasks and higher skills.

Direct instruction is not seen as the end of the learning process, but a way where students can be involved in more complex and challenging learning tasks; in other words, students are directly involved in a learning scenario from the delivery of material to the end of learning (Rymarz, 2013). In a lesson, students not only receive instructions but must understand all the forms that involve them.

This type of instructional learning has a unique contribution to children's education, and that this instruction is complementary to one another (van der Graaf et al., 2019). Understanding and interpreting the task of motion is fundamental. This can make learning meaningful. Learning does not just happen like that, but some values can be accepted by students and then applied in the next life. Regarding the game of badminton is a sport that is growing and developing rapidly that can make the Indonesian nation and state proud. Badminton is a sport included in the game sports group, can be played indoors or outdoors on a field that is little bylines in a predetermined length and width.

Learning the game of badminton in schools will be reflected in the quality of teaching teachers. One of the primary and essential moves is serving and serving as the beginning of a game and serving as the first attack in a match (Subarjah, 2010). Therefore, serving is considered necessary, among other essential skills, to get the point in the game (Arganata, 2016). Furthermore, service strokes are the initial capital for players to be able to win matches in badminton. A player who cannot serve correctly will take a fault. According to (Subarjah, 2010) the service shot is a shot with a racket that hits the shuttlecock to another field diagonally and aims to open the game and is an essential shot in badminton.

\section{METHOD}

The method used in this research is the mixing method (Ramadan \& Juniarti, 2020). The mixed-method research method can be interpreted as a research method by combining two research methods: qualitative and quantitative, in research activity. More comprehensive, valid, reliable, and objective data will be obtained (Sugiyono, 2010). In looking for serviceability, research is carried out with an experimental approach, while to find an understanding of service, direct interviews do it by 
researchers to the sample. The population in this study were all class VIII SMP Negeri 3 Darma Kuningan Regency, totaling 93 students. The sample was obtained using a cluster random sampling technique so that the class that was used as the research class was class VIII B totaling 28 students (Fraenkel, J. R., Wallen, N. E., \& Hyun, 2017). The research instruments in this study were service tests (Gazali \& Cendra, 2018) and interviews.

\section{RESULTS AND DISCUSSION}

Based on the result data analysis The research results obtained data as follows:

Table 1 Data Analysis

\begin{tabular}{cccc}
\hline \multirow{2}{*}{ Class } & \multicolumn{2}{c}{ Hypothesis testing } & \multirow{2}{*}{ Information } \\
& Z hit & Z daf & \\
\hline Experiment Class & 4,59 & 2,35 & Hi accepted \\
\hline
\end{tabular}

Based on the statistical calculation table obtained Z Hit (4.59) > Z daf (2.35), the $\mathrm{Hi}$ received means the influence of the direct instruction model on serviceability in badminton games in class VIII of SMP Negeri 3 Darma, Kuningan Regency in 2016 at the level of confidence (a) 0.05. The interview results were analyzed and concluded that the respondents knew and understood the importance of serving as an initial attack to get points in a game. Based on the results of the research that has been stated, the following are the results of the discussion;

There is an effect of the direct instruction model on serviceability in badminton games.

These results reveal that the direct instruction model can make movement tasks structured and well understood by students in line with the theory. This model allows students to be guided by a series of motion tasks presented by the teacher (Shibinski \& Martin, 2003), and students follow the instructions given by the teacher and then imitated. The choice of model will also be a concern for the teacher when delivering a subject matter (Cothran \& Kulinna, 2006). Characteristics of the game of badminton in particular to improve serviceability.

There is an effect of the direct instruction model on the understanding of service benefits. 
Understanding a movement task by interpreting the function of the movement is very important. Meaningful learning will make students good at carrying out movement tasks and innovative in interpreting the meaning of a movement (Suherman, 2016). In this study, the function of the service is not only a form of basic technique but in it, there is a function that is very important in getting points-the beginning of the game that can make an advantage in playing badminton (Ardyanto, 2018).

\section{CONCLUSION}

This study reveals that the direct instruction model can make movement tasks structured and well understood by students. This model allows students to be guided by a series of motion tasks presented by the teacher (Shibinski \& Martin, 2003), and students follow the instructions given by the teacher and then imitated. The choice of model will also be a concern for the teacher when delivering a subject matter (Cothran \& Kulinna, 2006). Characteristics of the game of badminton in particular to improve serviceability. Understanding a movement task by interpreting the function of the movement is very important. Meaningful learning will make students good at carrying out movement tasks and innovative in interpreting the meaning of a movement (Suherman, 2016). In this study, the function of the service is not only a form of basic technique but in it, there is a function that is very important in getting points-the beginning of the game that can make an advantage in playing badminton (Ardyanto, 2018).

\section{REFERENCES}

Abduljabar, B. (2011). Pengertian pendidikan jasmani. IImu Pendidikan, 1991.

Ardyanto, S. (2018). Peningkatan Teknik Servis Pendek Pada Bulutangkis Melalui Media Audio Visual. Jurnal IImiah Penjas, 4(3).

Arganata, M. A. (2016). Kekalahan Pemain Bulutangkis Ganda Putra Indonesia Dari Pemain Ganda Putra Korea. Jurnal Kesehatan Olahraga, 06(2).

Cothran, D. J., \& Kulinna, P. H. (2006). Students' perspectives on direct, peer, and inquiry teaching strategies. Journal of Teaching in Physical Education, 25(2). https://doi.org/10.1123/jtpe.25.2.166

Fraenkel, J. R., Wallen, N. E., \& Hyun, H. H. (2017). How to design and evaluate 
research in education. McGrawHill, 91.

Gazali, N., \& Cendra, R. (2018). Badminton Long-serve Skill's Level of Physical Education Male Students in the Universitas Islam Riau. Active: Journal of Physical Education, Sport, Health and Recreations.

Jumhana, \& Agustan, B. (2016). Pengaruh Model Directinstruction terhadap Teknik Dasar Dribbling dalam Permainan Sepak Bola. JUARA : Jurnal Olahraga, 1(1), 46-50. https://doi.org/https://doi.org/10.33222/juara.v1i1.57

Ramadan, G., \& Juniarti, Y. (2020) Metode penelitian: pendekatan kuantitatif, kualitatif dan R\&D. CV Sadari Press

Rymarz, R. M. (2013). Direct instruction as a pedagogical tool in religious education. British Journal of Religious Education, 35(3). https://doi.org/10.1080/01416200.2013.781992

Shibinski, K., \& Martin, M. (2003). Using directed instruction to teach initial psychomotor-skill acquisition. In Athletic Therapy Today (Vol. 8, Issue 2). https://doi.org/10.1123/att.8.2.34

Subarjah, H. (2010). Hasil Belajar Keterampilan Bermain Bulutangkis Studi Eksperimen pada Siswa Diklat Bulutangkis FPOK-UPI. Jurnal Cakrawala Pendidikan, 3(3). https://doi.org/10.21831/cp.v3i3.361

Sugiyono. (2010). Metode penelitian kuantitatif kualitatif dan $R \& D$. Alfabeta.

Suherman, A. (2016). The Analysis of Character Education in Teaching Physical Education. https://doi.org/10.2991/icieve-15.2016.50

van der Graaf, J., van de Sande, E., Gijsel, M., \& Segers, E. (2019). A combined approach to strengthen children's scientific thinking: direct instruction on scientific reasoning and training of teacher's verbal support. International Journal of Science Education, 41(9).

https://doi.org/10.1080/09500693.2019.1594442 